\title{
ACERCA DE LAS CAPACIDADES
}

\author{
JUAN CARLOS D'ALESSIO \\ Consejo Nacional de Investigaciones \\ Científicas y Técnicas Argentina
}

Austin considera que es plausible un análisis de Moore de acuerdo con el cual 'puedo hacer $x$ ' significa lo mismo que 'tendré éxito al hacer $x$ si lo intento' y 'hubiera podido hacer $x$ ' lo mismo que 'hubiera tenido éxito al hacer $x$ si lo hubiera intentado'.

Sin embargo Austin objeta este análisis porque, en contra de lo que permitiría concluir, no es lógicamente contradictorio afirmar que alguien no tuvo éxito al realizar una acción y que posee la capacidad para lograrla. ${ }^{2}$ Otra consecuencia objetable del análisis de Moore es que permite concluir que es lógicamente contradictorio afirmar que alguien tendrá éxito al realizar una acción y que carece de la capacidad correlativa. Sin embargo, hay situaciones en las que afirmamos ambos enunciados.

En el presente trabajo argumentaré que la aceptación del análisis anterior, que sigue las recomendaciones de la teoría empirista del significado, limita las posibilidades expresivas y predictivas del lenguaje. No desarrollaré en detalle nuestra posición acerca de las capacidades que evita los problemas mencionados, ya que este tópico lo tratamos en un libro, actualmente en preparación, acerca de las disposiciones, sólo indicaré que este punto de vista acepta una posición realista respecto de las propiedades, incluyendo las capacidades.

Comenzaremos por examinar una situación en la que al-

1 Austin, J. L. Philosophical Papers, Oxford 1961, p. 166.

2 Austin, op. cit. p. 166 No. 1 
guien tuvo y tendrá éxito para realizar una acción, a pesar de no poseer la capacidad que en condiciones normales tal éxito hubiera manifestado. Un médico, curando la mano de su paciente, puede indicarle que aunque realiza algunos movimientos, todavía no ha recuperado la capacidad de emplear esa mano en todas las circunstancias.

Naturalmente una acción es considerada como exitosa debido a que la misma se realizó con un propósito determinado cuya eficacia en el logro ha sido favorablemente evaluada. Una capacidad puede manifestarse en una variedad de circunstancias, pero algunas son más propias que otras para confirmarla.

Los éxitos no asociadas con la existencia de una capacidad serían aquéllos en los que hay elementos de juicio diferentes de la realización de la acción misma, que indican que tal capacidad no existe o al menos que no existe en el sentido más amplio. En el ejemplo considerado anteriormente, el médico puede basar su diagnóstico en un examen radiológico o en la historia clínica del paciente, para concluir que no posee la capacidad o que posee una capacidad limitada; estas observaciones son suficientes para concluir que la inducción de una capacidad en base a éxitos no es una inferencia lógica; tal resultado puede requerir la evaluación de un cúmulo de circunstancias. Los éxitos que no están asociados con la capacidad usualmente confirmada por ellos, serían aquellos en los que hay otras razones que disconfirman que se posea tal capacidad. Hemos afirmado que las capacidades pueden manifestarse en diferentes circunstancias, algunas de las cuales son menos favorables que otras para confirmarla; es razonable suponer que los éxitos no acompañados por la capacidad usual en ciertos casos pueden encontrarse en las situaciones menos favorables para manifestar la capacidad, aunque en otras pueden estar asociados con la existencia de otros elementos de juicio diferentes de las ocurrencias con que la capacidad se manifestó. 
Las observaciones anteriores hacen comprensibles tanto los ejemplos de éxitos sin las capacidades correspondientes como las de capacidades no acompañadas por éxitos. El ejemplo propuesto no es standard porque, como los éxitos son evidencia para las capacidades, no es standard afirmar que hay evidencia para capacidades sin que se las posea. En otros casos atribuimos éxitos a otros particulares dife. rentes de las capacidades mismas, tal como cuando lo atribuimos a la buena suerte o a la intervención de Dios; al negar que una acción es manifestación de nuestra capacidad, negamos que se trate de nuestro éxito.

La observación de Austin de que una capacidad es compatible con fracasos al intentar realizar la acción, puede ser comprendida en el mismo sistema de ideas, ya que un fracaso confirma al enunciado, negando que se posee la capacidad, pero esta evidencia puede no ser suficiente para disconfirmar que se la posea.

El hecho de que los ejemplos apuntados pueden no ser corrientes, no los hace inútiles, porque evitan que ciertas relaciones entre enunciados altamente confirmados sean consideradas como relaciones lógicas, o como parte del análisis de los términos empleados. Hemos argumentado que no es lógicamente contradictorio suponer que alguien tenga éxito al intentar realizar una acción pero que ésto no se deba a que sea capaz sino a que tenga buena suerte; por supuesto esta afirmación puede ser irracional y quizás sería deseable que no se efectuara, pero debe distinguirse entre la descripción de nuestro sistema conceptual, que realizamos en el presente trabajo, y la propuesta de reformularlo que no adelantamos. ${ }^{3}$ Similarmente nuestro lenguaje exhibe una tolerancia mayor, al aceptar que se puede poseer una capacidad a pesar de algunos fracasos, que la aceptada por el análisis que hemos considerado.

Nuestras observaciones no indican la única divergencia

3 Strawson, P. F. Individuals, Methuen, 1959, p. 9. 
entre nuestro uso de términos de capacidades y el establecido para los términos con los que se los desea analizar. Otra divergencia puede encontrarse en las diversas funciones de los predicados empleados. Cuando el profesor o el que contrata personal eligen a alguien, uno de los fundamentos de esa elección puede ser una comparación entre las capacidades de los candidatos, lo que permite predecir futuros éxitos de los candidatos más capaces. Sin embargo, si los predicados de capacidades fueran sustituidos por predicados incluyendo los analysans antes considerados, la explicación de quien realizó la selección no sería inteligible; solamente podría ser sustituida por un débil argumento analógico entre diferentes acciones y circunstancias, lo que constituiría una pérdida de poder explicativo y predictivo del lenguaje. 
Austin considers that there is some plausibility in Moore's analysis according to which ' $I$ can do $x$ ' means 'I shall succeed in doing $x$, if I try' and ' $I$ could have done $x$ ' means ' $I$ should have succeeded in doing $x$, if I had tried!' 1 However, Austin objects to this analysis because there is no logical contradiction between the statements that someone failed and that he has the capacity to succeed. Another objectionable conclusion from that analysis is that it leads to the conclusion that there is a logical contradiction between the statements that someone did not succeed in a performance and that he does not have the corresponding capacity in spite of the fact that there are situations in which we make these statements. In the present paper I shall argue that the acceptance of the previous analysis following the recommendations of the empiricist theory of meaning limits the explicative and predictive possibilities of the language. We shall not develop our position about capacities which avoids these difficulties for this is done in a book on dispositions which is at present in preparation. We shall only indicate here that our work includes a realist position about these properties.

Let us begin by examining examples of successes in a performance without having the corresponding capacity. An example of this type would be presented by a doctor healing the hand of a patient but who tells him that in spite of the fact that he movies his hand, still he has not recuperated his capacity in all circumstances.

Naturally an action is regarded as a success when it has been performed holding in mind a purpose whose efficiency for bringing about the intended result is evaluated favorably. Since a capacity may be manifested in a variety of circumstances some of which are more adequate than others to confirm it, successes not associated with the capacity normally confirmed by them would be instances in which there are other reasons to disconfirm that the person has the capacity or to confirm that he has a reduced capacity. We stated that successes not associated with a capacity can be found in less favorable circumstamces for the confirmation of the capacity, or in which there are other reasons to conclude that the capacity is not possessed by the person.

Our previous observations warrant the conclusion that the in- 
duction of a capacity based on successes is not a logical inference; in some cases this conclusion requires the examination of a variety of circumstances. When a success is not associated with the capacity normally confirmed by them, we may suppose that there are other evidences to confirm that the person does not possess that capacity. It was stated that capacities may be manifested in different circumstances, some of which are less favorable than others to confirm them; it may be assumed that successes not associated with the usual capacity may be found in less favorable circum. stances for the confirmation, though, in other cases may be found when there is evidence which might confirm a different capacity of the person.

Our previous observations clarify the existence of examples of successes not associated with a capacity, as well as Austin's exam. ples of capacities without successes. They are non-standard because, since successes are evidence for the capacities, it is not standard to state that we have evidence for a capacity without it. There are other examples of successes in which we exclude that they are manifestation of a capacity; as when we attribute them to good luck or God's intervention.

Austin's observation that a capacity is compatible with the existence of failures can be understood within the same framework because a failure confirms the statement denying that someone has a capacity, but this evidence may not be sufficient to refute that the persons has that capacity.

Even if the previous examples are not usual, their usefulness lies in the fact that they avoid the temptation of supposing that the relationship between highly confirmed nomological statements is a logical relationship.

One of the reasons for a choice among candidates by a teacher or a person employing personnel may be a comparison between the capacities of the applicants which justify the selection of the more capable candidates because in their case success in the performance of his future task in predictible. However if terms ap. plied to capacities were substitued by the analysans, the comparison between the capacities of the candidates would have to be substitued by a weak analogical argument between different actions, circunmstances and activities which would involve a loss, of the explicative and predictive powers of the language. 